\title{
ПЕДАГОГІЧНІ УМОВИ ВИКОРИСТАННЯ ІННОВАЦЙНИХ ТЕХНОЛОГІЙ В ОСВІТНЬОМУ ПРОЦЕСІ ЗВО
}

вищої школи, оскільки формує його інновативність, інноваційний потенціал, здатність створювати, сприймати та реалізовувати нововведення, координувати та регулювати інноваційні процеси в закладах вищої освіти.

Перспективи подальших розвідок у даному напрямі. Перспективи подальших розвідок щодо формування інноваційної культури викладача закладу вищої освіти ми вбачаємо у розробці моделі їі формування в освітньому процесі, позааудиторній діяльності, в процесі керівництва практикою студентів.

\section{ЛІТЕРАТУРА}

1. Вітвіцька С.С. Основи педагогіки вищої школи: методичний посібник. Київ, 2003.316 с.

2. Дичківська І.М. Інноваційні педагогічні технології: підручник. Київ, 2015. 304 с.

3. Козлова О.Г., Миленкова Р.В. Інноваційна культура: сутнісні характеристики: монографія. Суми, 2008. $140 \mathrm{c}$.
4. Ортинський В.Л. Педагогіка вищої школи: навчальний посібник. Київ, 2009. 472 с.

5. Щербань П.М. Навчально-педагогічні ігри: навчальний посібник. Київ, 2004. 240 с.

\section{REFERENCES}

1. Vitvitska, S.S. (2003). Osnovy pedahohiky vyshchoi shkoly: metodychnyi posibnyk [The fundamentals of Higher Education Pedagogy: A Toolkit]. Kyiv, 316p.[in Ukrainian].

2. Dychkivska, I.M. (2015). Innovatsiini pedahohichni tekhnolohii: pidruchnyk [Innovative pedagogical technologies: a textbook]. Kyiv, 304 p.[in Ukrainian].

3. Kozlova, O.H. \& Mylenkova, R.V. (2008). Innovatsiina kultura: sutnisni kharakterystyky: monohrafiia [Innovative culture: essential characteristics: a monograph]. Sumy, 140p. [in Ukrainian].

4. Ortynskyi, V.L. (2009). Pedahohika vyshchoi shkoly: navchalnyi posibnyk [Higher education pedagogy: a textbook]. Kyiv, 472 p. [in Ukrainian].

5. Shcherban, P.M. (2004). Navchalno-pedahohichni ihry: navchalnyi posibnyk [Educational and pedagogical games: a textbook]. Kyiv, 240 p. [in Ukrainian].

Стаття надійшла до редакції 23.12.2019

УДК: 371.134

DOI:

Лілія Бандура, аспірант ДВНЗ “Прикарпатський національний університет імені Василя Стефаника"

\section{ПЕДАГОГІЧНІ УМОВИ ВИКОРИСТАННЯ ІННОВАЦІЙНИХ ТЕХНОЛОГІЙ В ОСВІТНЬОМУ ПРОЦЕСІ ЗВО}

У статті розглянуто особливості використання інноваційних технологій в процесі навчання у вищій школі. Виконано аналіз науково-педагогічної літератури та документів, шо стосуються теми роботи. Висвітлено основні критерії гуманістичного навчання у $3 В О$ з використанням інновацій. Подано умови використання технологій та їх застосування зокрема, опрацьовано найпопулярніші класифікації інноваційних технологій різними науковиями. Презентовано нові авторські критерії для їх класифікаиії.

Ключові слова: інновачї; інновачійне навчання; інновачійні технологї; інтерактивні технологіi навчання; технологія модульного навчання; технологія проблемного навчання; дидактичні ігри.

Табл. 2. Літ. 10.

Liliya Bandura, Postgraduate Student, Precarpathian Vasyl Stefanyk National University

\section{PEDAGOGICAL CONDITIONS OF USING INNOVATIVE TECHNOLOGIES IN HIGH SCHOOLS' EDUCATIONAL PROCESS}

The article deals with the peculiarities of using the innovative technologies in higher education. The analysis of scientific and pedagogical literature and documents related to the topic of the work was performed. The basic criteria of humanistic education in the high school with using innovations are outlined. The article contains information about innovations and their place in the educational process today. Historical information about the origin of the term "innovative learning" is available. The stages of the "life" of pedagogical technologies are presented: from birth to their routineization. Terms of using technologies and their application in particular are presented. Amoung which interactive, modular and problem-based technologies, didactic games, etc. play an important role. An important role plays the emotional atmosphere, the psychological climate in the group during the class, interaction of all participants of the educational process, and using of the innovative technologies is the key to success in training. The most popular classifications of innovative technologies by different scientists have been worked out. In this article the new author's criteria for their classification are presented. The development will help university staff to choose the right pedagogical technology according to the purpose of the lesson. However, 


\section{ПЕДАГОГІЧНІ УМОВИВИКОРИСТАННЯ ІННОВАЦЙНИХ ТЕХНОЛОГІЙ В ОСВІТНЬОМУ ПРОЦЕСІ ЗВО}

the information available in the field of education on this topic is generalized and needs to be specified and elaborated. It would be advisable to consider the historical aspect of the formation of existing criteria for the classification of learning technologies.

Keywords: an innovation; an innovative training; innovative technologies; interactive learning technologies; module learning technology; problem-based learning technology; didactic games.

П остановка проблеми. Головний стратегічний план розвитку сучасної української педагогічної освіти спрямований на гуманізацію освітнього процесу, входження України до загальноєвропейського освітнього і наукового простору та адаптацію європейський стандартів у межах нашої держави. Досягнення поставлених цілей можливе тільки за систематизованої, логічної, послідовної та клопіткої роботи усіх освітніх ланок. Насамперед велика увага повинна приділятись вищій школі, оскільки вона формує ті якості педагогічного працівника XXI століття у майбутніх спеціалістів, які відповідають вимогам сучасного суспільства.

Для забезпечення виконання цього завдання в Україні розроблені нові стандарти освіти: “Стандарт вищої освіти України” спеціальності “Початкова освіта” (2016), “Державний стандарт початкової освіти” (2018), прийнятий у 2014 році Закон України “Про вищу освіту”, Концепція розвитку освіти України на період 2015 - 2025 років, проект Стратегії реформування вищої освіти в Україні до 2020 року та ін. Всі зазначені документи передбачають реформування освітньої галузі з метою формування незамінного фахівця з глибокими знаннями, необхідними вміннями та навичками через “навчання здобувачів вищої освіти сучасним науковим знанням з використанням новітніх інноваційних технологій” [7].

Аналіз останніх публікацій. Проблеми та перспективи впровадження інноваційних технологій в освітній процес розглядають Н. Дудник, Н. Насонова, В. Сенченко, О. Шестопал та ін. Застосування на практиці новітніх технологій та особливості їх застосування опрацювали В.І. Москалюк, О. Олійник, І. Підласий та ін. Трансформацію існуючих стратегій навчання на нові за допомогою педагогічних інноваційних технологій розкривають М. Кляп, В.І. Ковальчук та інші. Вчені відмічають, що найбільш перспективними є особистісно діяльнісні педагогічні технології, взаємопов'язані 3 модульним навчанням $[2,48]$. Однак особливості використання інновацій в освітньому процесі $3 \mathrm{BO}$ досліджені недостатньо.

Мета статті - розкрити особливості використання інноваційних технологій у підготовці майбутніх вчителів молодших класів.

Виклад основного матеріалу. На сьогодні загальновідомими є розуміння традиційного навчання.

Термінж “інноваційне навчання” запропонований групою вчених у доповіді Римського клубу (1978), який звернув увагу світової наукової громадськості на неадекватність принципів традиційного навчання вимогам сучасного суспільства до особистості, її пізнавальних можливостей. Інноваційне навчання спрямоване на формування готовності особистості до динамічних змін у соціумі за рахунок розвитку здібностей до творчості, різноманітних форм мислення, а також здатності до співробітництва 3 іншими людьми [5, 17].

Інноваційним $\epsilon$ не будь-яке нововведення, а лише те, що істотно підвищує результати певного виду діяльності. Інноваційне навчання зорієнтоване на динамічні зміни в навколишньому світі, це навчальна та освітня діяльність, яка грунтується на розвитку різноманітних форм мислення, творчих здібностей, високих соціальноадаптаційних можливостей особистості $[1,100]$.

Сьогодні інновації в освітньому процесі ЗВО повинні носити гуманістичний характер, тобто бути особистісно-зорієнтованими. А це передбачає:

- підтримку позитивної атмосфери в роботі;

- налагодження дружніх стосунків в системі “викладач-вихованець”;

- врахування інтересів, задатків, потреб вихованців при взаємодії $з$ ними та відповідна подача матеріалу;

- створення такого навчального середовища за якого творчі здібності та задатки вихованця розкриються максимально.

В контексті застосування нових інноваційних технологій у ЗВО центром тяжіння стає студент, який самостійно обирає траєкторію в освітньому середовищі. Щодо викладача, то він повинен бути наділений такими якостями, які сприяють формуванню критичного мислення вихованців.

Цікавим здається визначення життєвих циклів технології під якими розуміються стадії від зародження технологічних нововведень до їх рутинізації, де видаляється п’ять етапів (див табл. 1):

Як видно з таблиці, серед інноваційних технологій можна виділити два потужних блоки, які мають величезний вплив на навчання - це інформаційні технології та дистанційне навчання $[8,26]$. 
Таблиця 1.

Життсві цикли технології

\begin{tabular}{|c|}
\hline $\begin{array}{c}\text { 1.Новітня технологія } \\
\text { (будь-яка нова технологія, яка має високий потенціал) }\end{array}$ \\
\hline $\begin{array}{c}\text { 2.Передова технологія } \\
\text { ( технологія, яка зарекомендувала себе, але ще досить нова, має невелике- поширення на ринку) }\end{array}$ \\
\hline $\begin{array}{c}\text { 3.Сучасна технологія } \\
\text { ( визнана технологія, } \epsilon \text { стандартом, підвищується попит на цю технологію) }\end{array}$ \\
\hline $\begin{array}{c}\text { 4.Не нова технологія } \\
\text { ( як і раніше корисна технологія, але вже існує більш нова технологія, тому попит- починає падати }\end{array}$ \\
\hline $\begin{array}{c}\text { 5.Застаріла технологія } \\
\text { (технологія застаріває і замінюється досконалішою, дуже малий попит, або повна відмова від цієї } \\
\text { технології на користь нової) }\end{array}$ \\
\hline
\end{tabular}

Для забезпечення ефективності навчання та його результативності у закладах вищої освіти пропонується використання інноваційних технологій. Загальновідомим $є$ те, що чим цікавіше та активніше навчання, чим більше взаємодії на рівні “педагог-студент”, “студентстудент”, чим більше знань застосовуються на практиці, тим кращими є результати. Недарма Конфуцій понад 2400 років тому сказав: “Те, що я чую, я забуваю. Те, що я бачу, я пам'ятаю. Те, що я роблю, я розумію”. Це означає, що підготовка студентів до виконання професійних обов'язків має виконуватись так, щоб студенти були, в першу чергу, мотивовані, зацікавлені, активні й креативні.

Найпоширенішими при підготовці вчителя початкових класів у ЗВО інноваційними технологіями вченими Н. Дичківською, О. Пометун та ін. визначено:

- інтерактивні технології навчання (“inter" - взаємний, “асt”- діяти) - це спеціальна форма організації пізнавальної діяльності, що передбачає створення комфортних умов навчання, за яких студент відчуває свою успішність та інтелектуальну спроможність. Характерною ознакою інтерактивного навчання є постійна, активна взаємодія усіх учасників навчального процесу. Аналізуючи свої дії та дії своїх партнерів, кожен може змінювати модель своєї поведінки, більш усвідомлено засвоювати необхідні знання та вміння, відчувати себе в умовах, максимально наближених до майбутньої професійної діяльності. Найпоширенішими є: метод проектів, групові обговорення, “мозковий штурм”, ділові та рольові ігри, кейс-метод, тренінг-навчання, практичний експеримент, робота в парах, групах тощо[2, 49];

- технології модульного навчання - пакет науково адаптованих програм для індивідуального навчання, що оптимізує на практиці академічні та особистісні досягнення студента 3 певним рівнем попередньої підготовки [9].
- технології проблемного навчання дозволяє показати студентам зразки рішень, технологію аналізу проблеми і вироблення рішень, побудова доказів і аргументацій, освоєння алгоритмів вирішення проблемних ситуацій. При організації проблемного навчання можна обійтися, як вважають фахівці, без розумного поєднання традиційних технологій навчання 3 репродуктивними, пояснювально-ілюстративними, пошуковими, експериментальними і евристичними технологіями, що активізують взаємодію учасників освітнього процесу [10].

- дидактичні ігри - характеризуються чітко поставленою навчальною метою з орієнтацією на відповідний педагогічний результат. До дидактичних ігор відносять сюжетно-рольові ігри, ігри-вправи, ігри-драматизації, ігри-конструювання, ділові ігри, а також: дидактичні ігри лише комунікативної форми, ті, що поєднують комунікативні форми та практичні дії, комунікативні форми, наочність і предмети. За рівнем пізнавальної діяльності розрізняють репродуктивні ігри (формують необхідні знання і уміння); проблемно-пошукові (передбачають елементи пошуку, здійснення логічних операцій), творчі (спрямовані на виявлення індивідуального творчого потенціалу) [4, 223].

I. Підласий виділяє три базові технології, які $\epsilon$ принципово відмінними між собою в організації навчально-виховного процесу:

- предметно-зорієнтоване навчання - скероване на засвоєння мети;

- особистісно-зорієнтоване навчання скероване на задоволення потреб учня;

- співпраці (партнерства) - яка узгоджує задоволення потреб викладача та студента й основну мету навчання [6, 68].

Інноваційні педагогічні технології за змістовим критерієм та способом передачі інформації можна класифікувати на: інтерактивні технології навчання 


\section{ПЕДАГОГІЧНІ УМОВИ ВИКОРИСТАННЯ ІННОВАЦЙНИХ ТЕХНОЛОГІЙ В ОСВІТНЬОМУ ПРОЦЕСІ ЗВО}

та викладання (створення комунікативного середовища в повній взаємодії студента та викладача); розвивально-інтегровані технології (реалізація ігрової і емоційної взаємодію викладача і студента через реалізацію сценарію гри, ділового спілкування); проектні технології (розробка навчального проекту та плану його реалізації); інформаційно-комунікативні технології навчання та викладання (реалізація навчаючих програм в системі “викладач - комп'ютер - студент”); модульно-рейтингові технології (поглиблення i систематизування знань, умінь та навичок, розвиток самостійність студентів) $[3,100]$.

На основі класифікацій I. Підласого та В.I Ковальчук ми розробили власну, представлену в таблиці 2. теми чи окремих питань заняття, пошуку вирішення якоїсь проблеми; технічні використовуються за участі технічних засобів (планшету, проектора, комп’ютера чи мобільного телефону); творчі - мають на меті розвивати творчі здібності студентів, уяву, увагу, вміння творити руками, адже вчитель молодших класів повинен вміти все.

Висновки та перспективи подальших досліджень. Отже, інноваційні технології значно полегшують роботу викладача, наповнюють їі цікавим змістом, дозволяють пояснити важкодоступний матеріал простіше. На сьогодні існує багато інноваційних методів, способів та прийомів роботи, які представлені у ряді класифікацій.

Інноваційні технології сьогодні створюють

Класифікація інноваційних технологій навчання У $3 В 0$

\begin{tabular}{|c|c|c|c|c|}
\hline \multicolumn{2}{|c|}{ За способом підготовки } & \multicolumn{3}{|c|}{ За способом виконання } \\
\hline $\begin{array}{c}\text { Потребують } \\
\text { попередньої } \\
\text { підготовки }\end{array}$ & $\begin{array}{c}\text { Не завжди } \\
\text { потребують } \\
\text { попередньої } \\
\text { підготовки, або не } \\
\text { потребують взагалі }\end{array}$ & Розмовні & Технічні & Творчі \\
\hline $\begin{array}{c}\text { Метод } \\
\text { проекту,модульне } \\
\text { навчання, } \\
\text { інформаційно- } \\
\text { комунікаційні } \\
\text { технології, модульно- } \\
\text { рейтингові та ін. }\end{array}$ & $\begin{array}{c}\text { Ділові, рольові ігри, } \\
\text { “асоціативний кущ”, } \\
\text { дебати, “лицем до } \\
\text { лиця”(різновид } \\
\text { “мозкової } \\
\text { атаки”,проблемне } \\
\text { навчання (у випадку } \\
\text { імпровізації } \\
\text { проблеми) }\end{array}$ & $\begin{array}{l}\text { Ділові ігри, } \\
\text { дебати, } \\
\text { “мозковий } \\
\text { штурм”, } \\
\text { групові } \\
\text { обговорення } \\
\text { тощо. }\end{array}$ & $\begin{array}{c}\text { Іноформацій- } \\
\text { но-комунікаційні } \\
\text { технології, } \\
\text { модульно- } \\
\text { рейтингові } \\
\text { (візуалізація } \\
\text { результатів за } \\
\text { допомогою } \\
\text { діаграм, таблиць } \\
\text { тощо), проектні в } \\
\text { окремих випадках. }\end{array}$ & $\begin{array}{c}\text { Практичний } \\
\text { експеримент, } \\
\text { метод проекту } \\
\text { (окремі } \\
\text { випадки), ігри- } \\
\text { драматизації, } \\
\text { сюжетно- } \\
\text { рольові ігри, } \\
\text { тренінг } \\
\text { навчання та } \\
\text { інші. }\end{array}$ \\
\hline
\end{tabular}

Використання інноваційних технологій, відповідно до мети та завдань заняття, не завжди потребує попередньої підготовки. Професійний викладач може імпровізувати протягом лекції чи семінарського заняття і в ході пояснення давати студентам різні інтерактивні завдання, ігри, ситуаційні та проблемні завдання. Наприклад: уявіть, що в школі раптово відключили електроенергію, а у Ви запланували на уроці переглянути навчальний фільм. Як викрутитись? Чи: Ви помітили в класі прояви негативу до одного 3 учнів. Обговоріть в групах (по 3 чол.) як провести бесіду на тему “Стоп боулінг”.

Мета і завдання лекційного, практичного чи лабораторного заняття диктують технології та методи, які доцільно використати, щоб краще донести інформацію студентам. Так, за способом виконання педагогічних навчальних технологій можемо виділити: розмовні - передбачають максимальне залучення студентів до обговорення найсприятливіші умови навчання для підготовки майбутнього спеціаліста. Робота педагогічного ЗВО не може обійтись без інтерактивних та комп'ютерних технологій, дидактичних ігор, оскільки вони не тільки активізують і мотивують студентів до навчання, а ще й неодмінно стануть у нагоді в майбутній роботі. Робота вчителів молодших класів повинна бути наповнена інноваціями. Вважаємо наше дослідження доцільним, оскільки за серед добре відомих класифікацій ми змогли виділити ще кілька неопрацьованих на сьогодні критеріїв, за допомогою яких викладач та майбутній фахівець зможе обрати оптимальний вид роботи для конкретного заняття. Проте ряд загальнодоступної інформації по темі статті $є$ узагальнений і потребує більшої конкретизації та опрацювання.

\section{ЛІТЕРАТУРА}

1. Дудник Н. Застосування інноваційних технологій в освіті України. Молодь і ринок. 


\section{ПЕДАГОГІЧНІ УМОВИ ВИКОРИСТАННЯ ІННОВАЦІЙНИХ ТЕХНОЛОГІЙ В ОСВІТНЬОМУ ПРОЦЕСІ ЗВО}

Щомісячний науково-педагогічний журнал. Дрогобич, 2010. №12 (71). С. 99-103.

2. Кляп М. Інноваційні методи навчання у ВНЗ як інструмент інтернаціоналізації вищої освіти України. Вища освіта України. №4. 2015. С. 4553.

3. Ковальчук В. І. Формування індивідуальних стратегій навчання засобами інноваційних педагогічних технологій. Молодий вчений. Київ, 2018. №12 (64). С. 100-102.

4. Москалюк В. І. Дидактична гра як ефективний метод підготовки фахівців соціальної сфери. Вісник ЛДУ БЖД. Львів, 2016. №13. C.221-225.

5. Олійник О. Про трактування поняття “педагогічна технологія". Рідна школа. Волинь, 2004. № 2. С. $16-19$.

6. Підласий І. Практична педагогіка або три технології: інтерактивний підручник для педагогів ринкової системи освіти. Видавничий Дім “Слово”. Київ, 2004. С. 64 - 74.

7. Проект Стратегії реформування вищої освіти в Україні до 2020 року. URL: http:// mon.gov.ua/ua/pr-vidd il/1312/1390288033/ 1415795124/

8. Сенченко В. О., Шестопал О.В., Насонова Н.А. Впровадження інноваційних технологій в освіті: виклик XXI сторіччя, проблеми та перспективи. Сучасні інформаційні технології та інноваційні методики навчання в підготовці фахівців: методологія, теорія, досвід, проблеми. Збірник наукових праць. Вінниця, 2018. С. 25 - 28.

9. Технологія модульного навчання. URL: https://pidruchniki.com/10810806/pedagogika/ tehnologiya modulnogo navchannya

10. Технологія проблемного навчання. URL: https://stud.com.ua/88191/pedagogika/ tehnologiyi problemnogo_navchannya

\section{REFERENCES}

1. Dudnyk, N. (2010). Zastosuvannia innovatsiinykh tekhnolohii v osviti Ukrainy [Application of innovative technologies in education of Ukraine]. Youth \& market, No. 12 (71). pp. 99-103. [in Ukrainian].

2. Kliap, M. (2015). Innovatsiini metody navchannia u VNZ yak instrument internatsionalizatsii vyshchoi osvity Ukrainy [Innovative teaching methods at universities as a instrumentality for internationalization of higher education in Ukraine]. Higher education inUkraine. Kyiv, No. 4. pp. 4553. [in Ukrainian].
3. Kovalchuk, V. I. (2018). Formuvannia indyvidualnykh stratehii navchannia zasobamy innovatsiinykh pedahohichnykh tekhnolohii [Formation of individual strategies of teaching by means of innovative pedagogical technologies]. Young scientist. Kyiv, No. 12 (64). pp. 100-102. [in Ukrainian].

4. Moskaliuk, V. I.(2016). Dydaktychna hra yak efektyvnyi metod pidhotovky fakhivtsiv sotsialnoi sfery [Didactic game as an effective method of training specialists in the social environment]. Visnyk LDU BZhD. Lviv, No. 13. pp. 221-225. [in Ukrainian].

5. Oliinyk, O. (2004). Pro traktuvannia poniattia "pedahohichna tekhnolohiia" [The interpretation of the concept of "pedagogical technology"]. Native school. Volyn, No. 2. pp. 16 - 19. [in Ukrainian].

6. Pidlasyi, I. (2004). Praktychna pedahohika abo try tekhnolohii: interaktyvnyi pidruchnyk dlia pedahohiv rynkovoi systemy osvity [Practical pedagogy or three technologies: an interactive textbook for educators of the market-based education system.]. Kyiv. pp. 64 - 74. [in Ukrainian].

7. Proekt Stratehii reformuvannia vyshchoi osvity v Ukraini do 2020 roku [Draft Strategy for Higher Education Reform in Ukraine by 2020]. Avaliable at: http://mon.gov.ua/ua/pr-vidd il/1312/1390288033/ 1415795124/ (Accessed 12 Nov. 2014). [in Ukrainian].

8. Senchenko, V.O., Shestopal, O.V.\& Nasonova, N.A. (2018). Vprovadzhennia innovatsiinykh tekhnolohii v osviti: vyklyk XXI storichchia, problemy ta perspektyvy. Suchasni informatsiini tekhnolohii ta innovatsiini metodyky navchannia $\mathrm{v}$ pidhotovtsi fakhivtsiv: metodolohiia, teoriia, dosvid, problemy [Implementation of Innovative Technologies in Education: The Challenge of the 21st Century, Challenges and Prospects. Modern information technologies and innovative teaching methods in the training of specialists: methodology, theory, experience, problems]. Collection of scientific works. Vinnytsia. pp. 25 - 28. [in Ukrainian].

9. Tekhnolohiia modulnoho navchannia [Modular learning technology]. Avaliable at: https:// pidruchniki.com/10810806/pedagogika/ tehnologiya modulnogo navchannya [in Ukrainian].

10. Tekhnolohiia problemnoho navchannia [Problem learning technology]. Avaliable at: https:// s t u d . com.ua/88191/pedagogi ka/ tehnologiyi problemnogo navchannya [in Ukrainian].

Стаття надійшла до редакції 12.12.2019

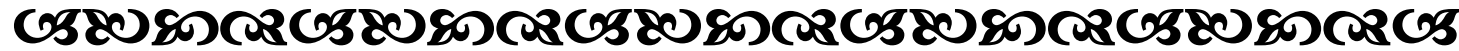

